DOI: 10.15393/j9.art.2012.351

Елена Анатольевна Осокина

кандидат филологических наук, научный сотрудник Отдела экспериментальной лексикограбии, Институт русского языка Российской академии наук

(Москва, Российская Федерация)

lenazar@yandex.ru

\title{
ГИМНОГРАФИЧЕСКИЙ «КАНОН» В «ФОРМЕ ПЛАНА» «БРАТЬЕВ КАРАМАЗОВЫХ» ДОСТОЕВСКОГО
}

\begin{abstract}
Аннотация: В статье проводится параллель между богослужением и художественным творчеством на примере последнего крупного произведения $Ф$. М. Достоевского. Во введении описывается канон как жанр и как богослужебное последование. Порядок песен в каноне и порядок богослужебного последования напоминает «последование» самого романа, делает его упорядоченным и узнаваемым. Форма, избранная Достоевским, была более органична для русского сознания, чем «роман» в его западном варианте, и более выразительна для художественного произведения. Придав своему роману форму гимнографического произведения - канона, Достоевский создал особую художественную форму, сделавшую его произведение совершенным. Форма канона как гимнографического жанра отражена в структуре («форме плана») романа, что сразу видно благодаря расположению жизнеописания старца Зосимы. Сокровенный смысл романа выражен в его форме. Именно структура канона, воспроизведенная в художественном произведении, позволила писателю соединить всеохватность и современность, поставить вечные, но животрепещущие, вопросы, связанные с утратой веры в Бога, и дать истинные ответы в обретении веры во Христа.

Ключевые слова: гимнография, канон, роман, кондак и житие, форма, русское христианское сознание, сопереживание, благодать, совершенная форма художественного произведения
\end{abstract}

Кто достоин раскрыть сию книгу и снять печати ее?

(Апокалипсис V, 2)

$\mathrm{O}$ собое притяжение, которым наделены «Братья Карамазовы», кроется в загадке, разгадывание которой становится смыслом жизни для читателей Достоевского, вопросом проникновения в тайну или преткновения перед наложенной на слова печатью. Произведение, венчающее творчество писателя, является сокровенным, но так, что скрытое становится явным для тех, кто читает «с открытыми глазами». И ключи к прочтению скрыты в самом тексте: на поставленные автором «вечные» вопросы даются истинные «в веках» ответы.

Христианское содержание романа - идею отвержения Бога и Его творения как величайшее зло и принятие искупительной жертвы Христа с осознанием собственной ответственности за свои и чужие прегрешения как спасения - Достоевский облекает в форму 
канона - особой гимнографической формы, составляющей содержательную основу суточного богослужения ${ }^{1}$. Форма традиционного романа в его западном варианте не соответствовала тем задачам, которые решал Ф. М. Достоевский: всеохватность, истина и благодать. Избрана была - узнана и воплощена - более динамичная и органичная для русского сознания богослужебная форма, ставшая и самостоятельным литературным жанром, которая сама по себе давала ответ: хваление Богу и всему сотворенному Им. Обретенная форма «Братьев Карамазовых» явилась столь емкой и все охватной, что и в творчестве Достоевского, и во всей русской классической литературе конца XIX в. стала совершенным образцом в искусстве Слова.

Книга в истории христианской культуры изначально была связана с ритуалом, являлась неотъемлемой частью православного богослужения, создавая единую форму - книгу как службу и службу как книгу: «В начале было Слово, и Слово было у Бога, и Слово было Бог» (Ин. 1:1). Образ мира как вечно разворачивающейся Книги и вечно звучащего Слова в непрерывно совершаемом действе был закреплен христианским ритуалом и преподнесен как образец: смотрите, читайте, участвуйте. Книга как художественное произведение в творчестве Достоевского становилась своеобразным сакральным текстом и воплощала священный ритуал. И люди, читающие этот текст, тоже становились участниками непрерывного действа, восходя к истинному его содержанию - восхвалению Бога и сотворенного Им мира. Такое направление мысль получала в том числе и благодаря избранной автором форме романа.

Каноном первоначально называлась церковная служба - полный состав каждого отдельного Богослужения (вечерни или утрени) и полный состав всех служений, совершаемых в определенный день. В обители преподобного Феодора Студита наименование «канон» получила большая по объему церковная песнь со строго выдержанным тематическим последованием песен. Эта всеохватная форма, объединяющая первоначально 12, а потом 9 песен, даже 8, потому что вторая песнь, из-за своего содержания, обычно отсутствует и существует только в великопостных канонах. Общая композиция канона разделяется на четыре части вставными произведениями: I часть (песни 1-3), после которой вставлялся небольшой гимнографический текст, посвященный празднику или святому; II часть (песни 4-6), после которой вставлялся кондак - более сложная и древняя гимнографическая форма, представляющая похвалу святому или событию священной истории, в которой раскрывается суть всего канона; III часть (песни 7-9), представляющая собой благодарственную песнь Богу трех отроков в «пещи огненной» ${ }^{2}$ и Богородицы ${ }^{3}$. После 9-й песни - IV часть - исполняется 
еще несколько гимнографических текстов и три хвалитных псалма - 148, 149 и 150. Затем следует славословие, которое заканчивается ангельским гимном Святый Боже, Святый Крепкий, Святьй Бессмертный, помилуй нас. В заключение утреня как бы возвращается к своему началу: снова поется праздничное песнопение, которое в соединении с начальными молитвами утрени составляет одну большую величественную молитву - прошение милости Божией. Такая круговая композиция символизирует вечное предстояние, где «день равен веку».

На структуру канона - основное содержание службы - накладывается еще четырехчастная структура, объединяющая 12 книг. Числа «4» и «12» соответствуют ежедневным, или вседневным, обычным службам в храме, называемым «часы». Всего часов (молитвословий, освящающих определенное время суток) четыре, состоят они из трех псалмов, нескольких стихов и молитв, включая кондак празднику или святому, и покрывают половину суточного круга богослужения. Часы соединялись с другими богослужениями суточного круга - с вечерней (9-й), с утреней (1-й), с Божественной литургией (3-й и 6-й). Литургия - общественное богослужение, за которым совершается таинство Святого причащения. Божественная литургия называется также Евхаристией - благодарением. Совершая ее, люди благодарят Бога за спасение рода человеческого от греха, проклятия и смерти жертвой, принесенной на кресте Его Сыном, Господом нашим Иисусом Христом. Эта служба не входит в суточный круг, но, являясь сутью и целью суточного богослужения, объединяет все остальные службы и «держит» этот вечный круг. Самое святое содержание службы скрыто и доступно только в сопереживании таинства. Это же происходит и в художественном тексте Достоевского: основное содержание вынесено за пределы видимого текста, и осознание его происходит в душе читателя, сопереживающего видимому слову.

В тексте романа время основных событий можно соотнести с третьим (утреннее пробуждение Мити, Алеша пришел к Катерине Ивановне говорить о спасении Мити), шестым (хвала природе Мити, приезд к старцу и ожидание Мити, моление пред иконой таинственного посетителя, тлетворный дух, исчезновение кошмара Ивана с появлением Алеши) и девятым («молитва над чашей» Дмитрия) часом. Видение Алеши о пире в Кане Галилейской вечером предваряет круг основных событий (или замыкает его, образуя круговую композицию вечности).

Надо отметить, что со временем, при посвящении службы святому, кондак после 6-й песни распространился до более крупной формы - «жития» святого. Исторически кондак представлял собой 
драматизированное историческое или агиографическое повествование, иногда в лицах, диалогизированное, иногда в форме проповеди, объединяя в себе разные словесные жанры.

Достоевский специально оговаривает важность этой части, в которой он помещает ответы на сложнейшие вопросы и видит спасение в том, чтобы взять и сделать себя же ответчиком за весь грех людской, тогда не останется места гордости сатанинской и отрицанию Бога ${ }^{4}$ :

В следующей книге произойдет смерть старца Зосимы и его предсмертные беседы с друзьями. Это не проповедь, а как бы рассказ, повесть о собственной жизни. Если удастся, то сделаю дело хорошее: заставляю сознаться, что чистый, идеальный христианин - дело не отвлеченное, а образно реальное, возможное, воочию предстоящее, и что христианство есть единственное убежище Русской Земли ото всех ее зол. Молю Бога, чтоб удалось, вещь будет патетическая, только бы достало вдохновения. А главное - тема такая, которая никому из теперешних писателей и поэтов и в голову не приходит, стало быть, совершенно оригинальная. Для нее пишется и весь роман, но только чтоб удалось, вот, что теперь тревожит меня! 5

По форме вставное житие старца Зосимы не вполне соответствует традиционной агиографической форме, так как оно написано от первого лица, но с указанием, что «по рукописи Алексея Федоровича Карамазова». До второй половины XVII в. - до «Жития протопопа Аввакума, им самим написанного» - житийное повествование велось от третьего лица:

Само собою, что многие из поучений моего старца Зосимы (или, лучше сказать, способ их выражения) принадлежат лицу его, то есть художественному изображению его. Я же хоть и вполне тех же мыслей, какие и он выражает, но если 6 лично от себя выражал их, то выразил бы их в другой форме и другим языком 6 .

То, что выбрана такая форма, соответствует художественному принципу Достоевского для этого произведения в целом, выраженного в названии пятой книги «Pro и contra». Это «обратное» решение делает закономерным своеобразное представление посмертных чудес «наоборот»у мощей старца и радостное принятие Христа Алешей у гроба старца после сомнения и колебания, навеянного разговором с Иваном:

Тут вводится в роман как бы чужая рукопись (Записка Алексея Карамазова), и само собою, что эта рукопись разграфирована Алексеем Карамазовым по своему. Здесь вставлю ропщущее NBene: в июньской книге, в главе «Великий Инквизитор», не только нарушены мои рубрики, но даже все напечатано сплошь, страниц 10 сряду, без перенесения на другую строчку даже. Это очень меня огорчило, и на это приношу Вам мою сердечную жалобу.

В подтверждение неслучайности наблюдения можно привести письмо Ф. М. Достоевского к Н. А. Любимову от 7 (19) августа 1879 г. из Эмса, где Достоевский считает, что и «1/10-й доли не удалось того 
выразить, что хотел». Но выделял книгу шестую как кульминационную точку романа и очень просил сохранить все разделения на главы и подглавы, как было у него.

Здесь следует обратить внимание на структурное деление романа по частям: три части, шестая книга завершает вторую часть, являясь кульминацией романа. В другом письме:

Я первоначально действительно хотел сделать лишь в 3-х частях. Но так как пишу книгами, то забыл (или пренебрег) поправить то, что давно замыслил. А потому и пришлю при письме в редакцию и приписку, чтоб эту вторую часть считать за две части, то есть за 2-ю и 3-ю, а в будущем году напечатана будет, стало быть, лишь последняя четвертая часть. Таким образом, 4-я, 5-я и 6-я книги романа составят вторую часть, а 7-я, 8-я и 9-я книги составят 3-ю часть. Во всех трех частях будет таким образом в каждой по три книги, и почти по ровному числу печатных листов. Такова же будет и 4-я часть, то есть в 3-х книгах и от 10 до одиннадцати печатных листов ${ }^{7}$.

Достоевский настойчиво говорит о девяти книгах и трех частях своего романа, а потом и о 4-й части. Кульминационной является вторая часть, состоящая из 4-й, 5-й и 6-й книг. Шестая книга называется «Русский инок» и представляет собой житие Зосимы, рассказанное им самим (что отступает от канонической формы жития, как в случае с протопопом Аввакумом), но записанное Алешей Карамазовым. Если учесть отсутствие в каноне второй песни, то по расположению житие святого после шестой песни в каноне совпадает с помещением в романе жития Зосимы с его беседами и поучениями в 6-ю из девяти книг, составляющих содержательную основу «Братьев Карамазовых». Принцип противопоставления, или диалогичности, принцип вопроса и ответа, pro и contra, выдержан на всех уровнях текста в широком смысле слова. Разрешается эта контроверса в житии и словах старца Зосимы, потому что главное для Достоевского показать, как «мимоидущий лик земной и вечная истина соприкоснулись тут вместе» 8 и как «перед правдой земною совершается действие вечной правды».

Многообразная тематика романа также целиком охватывается тематикой песен канона, в том числе тема детей и «русских мальчиков». Именно эта тема должна была послужить основой для развития дальнейшего действия романа, на что вроде бы есть намек в предисловии автора к роману. Детская тема занимала важное место в жизни писателя: незадолго до начала работы над романом умер трехлетний сын Алеша - и в его творении: книги вторая, четвертая, десятая и эпилог посвящены мальчикам - именно здесь он искал ответы на «проклятые» вопросы. Интересно, что изначально

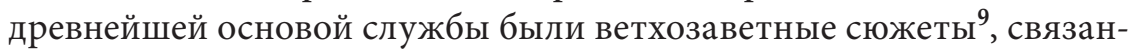
ные с чудесно спасшимися «тремя отроками в пещи огненной», ко- 
торые в последний час свой восхваляли Господа: Благословен еси, Господи Боже отеи, наших, и хвально и прославлено имя Твое во веки... (Дан 3:26-45), что и является содержанием всей службы.

Гимнографическая византийская традиция воспринята на Руси в X-XI вв. и за многие века своего существования органично усвоена русским христианским сознанием. Канонизированная форма службы была всеохватной, позволяющей объединять разнообразные темы. Как правило, в одно последование - что и есть «служба» - читалось сразу несколько «канонов», посвященных святым и (или) празднику этого дня. Поэтому сначала читались все первые тропари (иногда песни), затем вторые и т. д. Получалось сложнейшее переплетение текстов, как и в романе переплетаются истории трех братьев, их отца, нескольких женщин, и их объединение кажется упорядоченным и понятным. Видимо, и поэтому Ф. М. Достоевский выбрал для своего последнего произведения именно такую структуру, которая смогла вместить все его замыслы, рассуждения, сомнения, исповедь и дать ответ на животрепещущие вопросы современности. И этот ответ тоже связан с основным содержанием службы - хвалой Богу. Форма, избранная Достоевским, была органична для русского сознания и совершенна для художественного произведения.

\section{Примечания}

1 Это - первоначально - 12 песен, сгруппированных по три в 4 части, где после 3-й и 6-й песен вставлены дополнительные тексты, а перед 9-й - хвалебная песнь Богородицы. (См.: [1], [2]).

2 Дан. 3:26-45, 56-88.

3 Лк. 1:68-79.

4 ПСС 14-290. Достоевский Ф. М. Полн. собр. соч.: В 30 т. Л.: Наука, 1972-1986. Далее цитируем по этому изданию с указанием тома и страницы в скобках. Из письма Н. А. Любимову (11 июня 1879 г. Старая Русса - ПСС 30-1-131). Там же.

Н. А. Любимову. 16 ноября 1879 г. (ПСС, 30-1-131).

ПСС $14-265$.

7-8-я песни в каноне.

\section{Список литературы}

1. Никольский К. Пособие к изучению Устава Богослужения в Православной церкви. СПб.: Тип. А. И. Поповицкого и Кㅇ 1874.805 с.

2. Осокина Е. Методологические проблемы соотношения гимнографических и агиографических произведений // Гимнология. Материалы к Международной конференции. Москва. Сентябрь 1996 г. М., 2001. С. $178-187$. 


\title{
Elena Anatol'evna Osokina
}

Ph.D in Philology, Research Fellow, Department of Experimental Lexicography, Institute of Russian Language, Russian Academy of Sciences

(Moscow, Russian Federation) lenazar@yandex.ru

\section{HYMNOGRAPHIC 'CANON' AS A "FORM OF THE PLAN" IN "THE BROTHERS KARAMAZOV" BY DOSTOEVSKY}

\begin{abstract}
The article draws a parallel between divine service and art, using Dostoevsky's last grand masterpiece as an example. We begin by defining the canon as a genre and as a liturgical order. The order of songs in the canon and the liturgical order resemble the sequence of Dostoevsky's novel and make it ordered and recognizable. The form chosen by the author was more organic for Russian consequence than the novel in its Western version and more expressive for a piece of art. By shaping his novel into a canon as a hymnographic piece, Dostoevsky created a special form which helped his novel attain perfection. The form of canon as a hymnographic text is found in the novel's structure ("a form of a plan") which is made clear by the positioning of the life of Zosima. The novel's hidden meaning was thus expressed in its form. The structure of a canon reproduced in a piece of fiction allowed Dostoevsky to link the contemporary and the all-embracing, bring up eternally important issues of losing faith in God and provide true answers in the discovery of new faith in Jesus.
\end{abstract}

Keywords: Hymnography, canon, novel, kontakion, vita, form, Russian Christian consciousness, empathy, good fortune, perfect form of a work of art

\section{References}

1. Nikolskiy K. Posobie $k$ izucheniyu Ustava Bogosluzheniya v Pravoslavnoy tserkvi [Guide to the Study of the Church Services Charter in the Orthodox Church]. Saint-Petersburg, A. I. Popovitskiy Publ., 1874. 805 p.

2. Osokina E. Metodologicheskie problemy sootnosheniya gimnograficheskikh i agiograficheskikh proizvedeniy [Methodological Problems of the Correlation of Hymnographic and Hagiographical Works]. Gimnologiya. Materialy k Mezhdunarodnoy konferentsii. Moskva. Sentyabr' 1996 god [Hymnology. Materials for the International Conference. Moscow. September 1996]. Moscow, 2001, pp. 178-187. 